\author{
Güneş Çobanoğlu Ercan \\ Hülya Özay \\ Elif Bombacı \\ Banu Çevik \\ Serhan Çolakoğlu
}

\section{Yanık ve Yara Tedavi Merkezi Yoğun Bakım Ünitesinde Íki Yıllık Süreçte Takip Edilen Hastaların Prognozu}

\author{
The Prognosis of Two Year Follow up of \\ Burn Intensive Care Unit Patients
}

Geliş Tarihi/Received: 12.08 .2012

Kabul Tarihi/Accepted: 09.10.2012

Türk Yoğun Bakım Derneği Dergisi, Galenos Yayınevi tarafindan basılmıştır.

Journal of the Turkish Society of Intensive Care, published by Galenos Publishing.

ISNN: 1300-5804

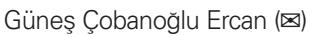

Konya Dr. Vefa Tanır Ilgın Devlet Hastanesi, Anesteziyoloji Reanimasyon Kliniği, Konya, Türkiye

Hülya Özay, Elif Bombacı, Banu Çevik,

Serhan Çolakoğlu

Istanbul Dr. Lütfi Kırdar Kartal Eğitim ve Araștırma Hastanesi, Anesteziyoloji ve Reanimasyon Kliniği, Istanbul, Türkiye

E-posta: gunescobanoglu@yahoo.com

Tel.: +903328816348
ÖZET Amaç: Bu çalışmada, yanık yoğun bakım ünitelerinde takip edilen hastaların prognozunu etkileyen faktörlerin tespit edilmesi amaçlandı.

Gereç ve Yöntem: Aralık 2008 ile Kasım 2010 tarihleri arasında hastanemizin yanık yoğun bakım ünitesinde tedavi edilmiş hastalar geriye dönük olarak incelendi. Yaș, cinsiyet, yanık yüzdesi, yatış endikasyonu, yanık yoğun bakım ünitesi ve hastanede kalıs süreleri, yanık yoğun bakım ünitesinden taburculuğu, yanık yoğun bakım ünitesinden çıkarılıp hastanede takip edilen hastaların taburculuğu, trakeotomi uygulaması, inotrop ilaç desteği, kabulde Glasgow koma skalası puanı, kabulde ve 24 . saatte APACHE II skorları, mekanik ventilasyon süreleri, tekrar yoğun bakım ünitesinde takip intiyacı, kan, doku/yara, trakea ve idrar kültür sonuçları parametreleri ile mortalite oranları karșılaștııldı.

Bulgular: Yanık yoğun bakım ünitesinde ölen hastaların yas ortalaması, taburcu olanlardan yüksek saptanmıştır $(p<0,01)$. Cinsiyetler arasında farklılık bulunmamaktadır $(p>0,05)$. Yanık yoğun bakım ünitesine yatıș nedenleri alev yanığı (\%50), elektrik yanıkları (\%22) suyla haşlanmaya bağlı yanıklar (\%17) ve diğerleri olarak saptandı. Yanık yoğun bakım ünitesinde mortalite oranı $\% 44,8$ olarak bulundu. Yanık yüzdesi arttıkça mortalitenin arttı̆̆ı gözlendi. Yanık yüzdesi \% 70 ve üzeri olan hastalarda ölüm oranı \%100 olarak saptandı. Yoğun bakımda ölen hastaların yanık yüzdeleri $(p<0,01)$, yatış APACHE II skorları ve 24 saatlik APACHE II skorları $(p<0,01)$, GKS skorları ( $p<0,01)$, taburcu olanlardan anlaml şekilde yüksek saptandı. Ölen hastaların mekanik ventilasyon süreleri, taburcu olanlardan yüksek bulundu $(p<0,01)$. Yanık yoğun bakım ünitesinden taburcu olan hastaların yanık yoğun bakım ünitesine tekrar yatışları da incelendi, oran \% 2,8 olarak bulundu. En sık ölüm nedeni sepsis ve çoklu organ yetmezliğiydi. Hastaların kan, doku/yara, trakea ve idrar kültür sonuçları ile mortalite ilişkisi incelendi. Kan, idrar ve doku/yara kültürlerinde üreme ile mortalite arasında anlamlı fark saptanmadı. Fakat ölen hastalarda, taburcu olanlara göre trakeada üreme daha fazlayken $(p<0,05)$ kateterde üreme daha az bulundu $(p<0,01)$

Sonuç: Çalışmamızda, yüksek yanık yüzdesinin, mekanik ventilasyon desteği süresinin, inotropik ilaç desteği ve 24 saatlik APACHE II skorunun yüksekliğinin mortaliteyi arttırdığı saptanmıştır.

Anahtar Kelimeler: Yanık yüzdesi, mortalite, yanık yoğun bakım ünitesi

SUMMARY Objective: The aim of this retrospective study was to determine the prognostic factors at the burn intensive care unit (BICU).

Material and Method: We retrospectively evaluated the patients who treated in BICU between December 2008 and November 2010. The relationship between mortality and the parameters such as age, gender, etiology of burn, burn percentage, discharge from BICU or not, discharge from hospital or not,

tracheotomy application, inotropic drug support treatment, GCS score, APACHE II score in admission and 24th hour APACHE II score, duration of mechanic ventilation, duration of hospitalization, blood, tissue/wound, trachea and urine culture results, cause of death were analyzed.

Results: The avarage age of patients who died in BICU was higher than the discharged ones $(p<0.01)$. There was no significant difference between genders $(p>0.05)$. 
The etiology of hospitalization to BICU were flame burns $(50 \%)$, electrical burns $(22 \%)$, boiling water burns $(17 \%)$ and others. The overall mortality was $44.8 \%$. The mortality ratio was $100 \%$ in patients who had $70 \%$ or higher burn percentage. The admission APACHE II scores, 24th hour APACHE II scores and the ratio of the patients who died in BICU were significantly higher than the discharged ones $(p<0.01)$. The mechanic ventilation support duration time of the patients who died in $\mathrm{BICU}$ was higher than the patients who discharged from BICU ( $p>0.01)$. Also we evaluated the BICU discharged patient readmission to BICU, 28\%. Sepsis and the multiple organ dysfunction were the most common causes of death. The relationship between the blood, tissue/wound, trachea, urine cultures positivity and mortality was analyzed but the results were not statistically significant. Despite these results, positivity of tracheal cultures were more in discharged patients than dead ones $(p<0.05)$ whereas positivity of catheter cultures were less $(p<0.01)$. Conclusion: In our study, we found that, the presence of high burn percentage, mechanic ventilation support duration time, inotropic drug support and high 24th hour APACHE II score increase the risk of mortality.

Key Words: Burn percentage, mortality, burn intensive care unit

\section{Giriş}

Son 20 yılda yanık hastaları için prognoz hem sağkalım hem de yaşam kalitesi açısından belirgin olarak iyileşmiştir. Bu değişim kaçınılmaz yara sepsisi gelişmeden, derin yaraları uzaklaştırmak ve hızla biyolojik kapanmanın sağlanması amacı ile uygun zamanda yapılan cerrahinin yanıkların doğal seyrini değiştirebileceğinin fark edilmesinin bir sonucudur (1).

Yanık hastasının durumu yanığın seyrine göre dramatik olarak değişebilir. Yanık sonrası süreçte ilk olarak sıvının yer değiştirmesine bağlı olarak kardiyopulmoner düzensizlik ve duman hasarına bağlı havayolu hasarı ortaya çıkar. Bunu yara yeri inflamasyonu, immünsupresyon, enfeksiyon ve metabolik parametre değişiklikleri takip eder. Monitörizasyon gereksinimi diğer yoğun bakım hastalarından farklı değildir. Ancak yara bakımı ile diğer yoğun bakım hastalarından ayrılır (2).

Ülkemizde de yanık ve yara tedavi ünitelerinin artmasıyla yanıklı hastalara daha iyi tedavi verilmeye başlanmıştır.

Bu çalışmada hastanemiz bünyesindeki yanık ve yara tedavi merkezinde bulunan 6 yataklı yanık yoğun bakım ünitesinde (YYBÜ) iki yıllık süreçte takip edilen yanık hastalarının özellikleri, yoğun bakım kalış süreleri, yoğun bakım mortalitesi ve mortaliteyi etkileyen faktörlerin belirlenmesi amaçlanmıştır.

\section{Gereç ve Yöntem}

Bu çalışmada hastanemizin yanık yoğun bakım ünitesinde Aralık-2008 ile Kasım 2010 tarihleri arasında 2 yıllık süreçte takip edilen hastaların dosyaları geriye dönük olarak tarandı. Hastaların:

- Yaş

- Cinsiyet

- Yanık yüzdesi

- Yatış endikasyonları

- Yandaş hastalıkları

- Yoğun bakımda ve serviste kalış süreleri

- Yoğun bakımdan taburcu olup olmadığı

- Yoğun bakımdan taburcu olup servise devredilen hastaların servisten taburcu olup olmadığı

- Trakeatomi açılıp açılmadığı

- Inotrop destek tedavisi alıp almadıkları
- Kabulde Glasgow Koma Skalası (GKS) puanı

- Kabulde ve 24 saat sonra hesaplanan APACHE II skorları

- Mekanik ventilasyon uygulanma süreleri kayıt edildi.

- Mekanik ventilasyon intiyacı olan tüm hastalarda inhalasyon hasarı da olduğu kabul edildi.

Dışlama kriteri uygulanmadı.

Çalışmada elde edilen bulgular değerlendirilirken, istatistiksel analizler için NCSS (Number Cruncher Statistical System) 2007\&PASS 2008 Statistical Software (Utah, USA) programı kullanıldı. Çalışma verileri değerlendirilirken tanımlayıcı istatistiksel metotların (Ortalama, standart sapma) yanı sıra niceliksel verilerin karşılaştırılmasında normal dağılım gösteren parametrelerin iki grup arası karşılaştırmalarında student t testi, normal dağılım göstermeyen parametrelerin iki grup arası karşılaştırmalarında Mann-Whitney U testi kullanıldı. Niteliksel verilerin karşılaştırılmasında ise ki-kare testi testi kullanıldı.

Çok değişkenli analiz için lojistik regresyon analizi kullanıldı. Anlamlılık p<0,05 düzeyinde değerlendirildi.

\section{Bulgular}

Yanık Yoğun Bakım Ünitesi'nde (YYBÜ) 2 yıllık süreçte 212 hasta takip ve tedavi edildi. Hastaların \%55,22'si yoğun bakımdan taburcu oldu. Yoğun bakım mortalitesi \%44,8 olarak bulundu. YYBÜ'ne yatıılan hastaların \%2,8'i tekrar yoğun bakıma yatırılmıştır. Tekrar yatan hastaların mortalitesi \%83'tür.

Cinsiyet dağılımında erkek hastaların oranı \% 77,4 (164 hasta) iken kadın hastaların oranı \%22,6 (48 hasta) idi. Hastaların yaşları 3 ay ile 83 yıl arasında değişmekte olup, ortalaması 29,57士19,57 yıldı.

Yoğun bakımda ölen hastaların yaş ortalaması, taburcu olanlardan istatistiksel olarak anlamlı şekilde yüksek saptanmıştır $(p<0,01)$. Yoğun bakımda ölen hastalarda cinsiyetler arasında istatistiksel olarak anlamlı farklılık bulunmamaktadır ( $p>0,05)$ (Tablo 1).

Yoğun bakım ünitesine yatış nedenleri karşılaştırıldığında en sık yatış nedeninin alev yanığı (\%50) olduğu görüldü. Alev yanığını elektrik yanıkları (\%22), haşlanmaya bağlı yanıklar (\%17), kimyasal yanıklar, toksik epidermal nekroliz (TEN), buhar yanıkları, alev ve elektrik yanığının birlikte olduğu yanıklar, inhalasyon yanıklarının takip ettiği görüldü (Tablo 2). 
Tablo 1. Ölen ve taburcu olan hastaların karşılaştıııması

\begin{tabular}{|c|c|c|c|c|}
\hline & & Taburcu & Ölen & $\mathbf{p}$ \\
\hline *Yaş & $\mathbf{N}$ & $\%$ & $\%$ & \\
\hline \multirow[t]{2}{*}{ Cinsiyet } & Kadın & $25(\% 21,4)$ & $23(\% 24,2)$ & 0,623 \\
\hline & Erkek & $92(\% 78,6)$ & $72(\% 75,8)$ & \\
\hline \multicolumn{2}{|c|}{ YYBÜ'de Kalış Süresi (gün) } & $6,83 \pm 7,69(3,5)$ & $8,70 \pm 7,95(6)$ & $0,004^{* *}$ \\
\hline \multicolumn{2}{|c|}{ Yanık Düzeyi (\%) } & $30,51 \pm 14,11(30)$ & $55,72 \pm 22,31(50)$ & $0,001 * *$ \\
\hline \multicolumn{2}{|c|}{ Gelişte APACHE II Skoru } & $13,53 \pm 3,87(14)$ & $16,92 \pm 4,02(17)$ & $0,001 * *$ \\
\hline \multicolumn{2}{|c|}{24 Saatlik APACHE II Skoru } & $12,74 \pm 3,96(12)$ & $16,94 \pm 4,92(17)$ & $0,001 * *$ \\
\hline \multicolumn{2}{|c|}{ GKS Skoru } & $14,31 \pm 2,35(15)$ & $13,09 \pm 3,45(14)$ & $0,001 * *$ \\
\hline
\end{tabular}

Mann-Whitney U testi kullanıldı, Ki-kare testi ${ }^{*}$ Student $t$ testi, ${ }^{*}$ $p<0,01$

Tablo 2. Yatış nedenleri dağılımı

\begin{tabular}{lcc}
\hline Yanık Nedeni & Hasta sayısı & Yüzde (\%) \\
\hline Alev & 106 & 50 \\
Elektrik & 46 & 22 \\
Haşlanma & 35 & 17 \\
Kimyasal & 9 & 4 \\
Buhar & 3 & 1 \\
Ten & 7 & 3 \\
Inhalasyon & 2 & 1 \\
Alev + Elektirik & 4 & 2 \\
TOPLAM & 212 & 100
\end{tabular}

Hastaların yoğun bakım ünitesine yatıştaki vücut yanık yüzdeleri dokuzlar kuralına göre hesaplandı (3). TEN tanılı ve sadece inhalasyon yanığı olan hastalar yanık yüzdesi hesabına katılmadı. Yanık yüzdeleri karşılaştııılı. Yanık düzeyleri \%10 ile $\% 100$ arasında değişmekte olup, ortalaması \%42,27 $\pm 22,26$ olarak bulundu. En sık \%30-39 ve 40-49 vücut yanık yüzdesine sahip hastaların yoğun bakımda takip edildiği gözlendi. Bunu $\% 20-29$ ve $\% 50-59$ vücut yanık yüzdesine sahip hastaların takip ettiği görüldü (Şekil 1).

Hastaların yanık dereceleri; görünümü, kıvamı, esnekliği ve ağrıı olup olmadığına göre sınıflandıııldı. Hastaların \%20'sinde birinci ve ikinci derecede yanık saptandı. Bu hastalar baș-boyun yanığı olması nedeniyle yoğun bakıma alınan hastalardı. Hastaların \%80'ninde ise ikinci, üçüncü ve dördüncü derecede yanıklar bir aradaydı.

Vücut yanık yüzdelerine göre hastaların mortalitesi sınıflandııılı. Vücut yanık yüzdesi arttıkça mortalitenin artıı̆ı görüldü. \%70 yanık yüzdesi ve üzerindeki yanığı olan hastalarda mortalite \%100 olarak saptandı. Yoğun bakımda ölen hastaların yanık yüzdeleri, taburcu olanlardan istatistiksel olarak anlamlı şekilde yüksek saptanmıştır

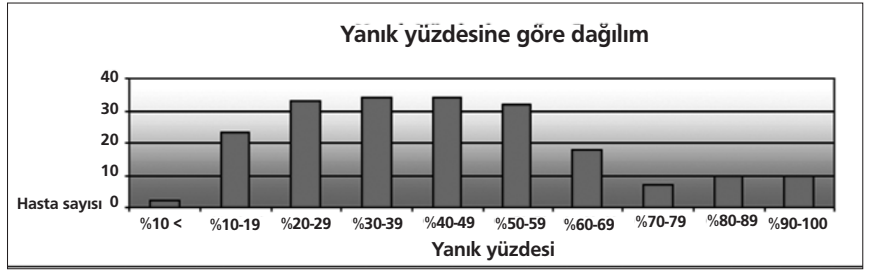

Şekil 1. Hastaların yoğun bakım ünitesine yatıştaki vücut yanık yüzdelerinin karşışaştırılması

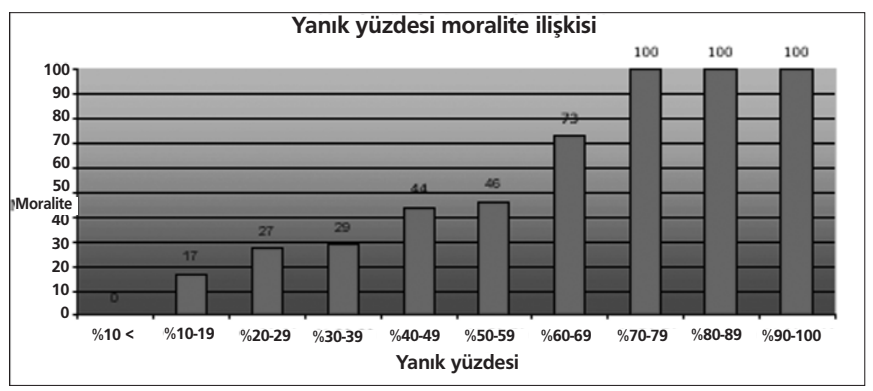

Şekil 2. Hastaların yoğun bakım ünitesine yatıştaki vücut yanık yüzdelerine göre hastaların mortalitesinin karşılaştıııması

$(p<0,01)$ (Tablo 1). Yanık yoğun bakım ünitesine yatırılan hastalardan 8'i $(\% 3,7)$ ilk görüldüğünde vücut yanık yüzdesi $\% 100$ 'dü. Bu hastalar takipleri 24 saati tamamlamadan öldü. Yanık dışında TEN tanılı 7 hasta yoğun bakım ünitesinde takip edildi. Bu hastalardan ikisi yatışlarından 7 gün sonra öldü, kalan 5'i evine taburcu oldu. Mortalite \%29 olarak hesaplandı. (Şekil 2).

Hastaların YYBÜ'de ve hastanede kalış süreleri incelendi. Yoğun bakımda kalış süreleri 13 ile 35 gün, hastanede kalış süreleri 1 ile 62 gün arasında değişmekteydi. Hastaların ortalama 7,66 $\pm 7,84$ gün yoğun bakımda, 13,68 $\pm 10,90$ gün ise hastanede yattığı görüldü. Yoğun bakımda ölen hastaların yoğun bakımda kalış süreleri, taburcu olanlara göre istatistiksel 
olarak anlamlı şekilde yüksek saptanmışıı $(p<0,01)$. Hastanede kalış süreleri incelendiğinde istatistiksel olarak anlamlı farklılık bulunmamaktadır ( $p>0,05)$ (Tablo 1).

Yoğun bakıma yatıılan hastaların \%44,8'i yoğun bakımda ölmüş, servise taburcu olan hastalarda ölüm görülmemiştir.

Hastaların yatıştaki GKS değerleri; yatıştaki ve 24 saat sonraki APACHE skorları hesaplandı. GKS skorları 3 ile 15 arasında değişmekte olup, ortalaması $13,78 \pm 2,94$ 'tür. Hastaların yatış APACHE skorları ile yatıștan 24 saat sonraki APACHE skorları

karşılaştıııldığında, 24 saat sonraki APACHE değerleri daha düşük bulundu. Yatış APACHE II skorları 1 ile 26 arasında değişmekte olup, ortalaması 15,04 $\pm 4,28 ; 24$ saatlik APACHE ॥ skorları da 1 ile 29 arasında değișmekte olup, ortalaması $14,60 \pm 4,88$ olarak hesaplandı (Tablo 1). Yoğun bakımda ölen hastaların yatış APACHE II skorları ve 24 saatlik APACHE ॥ skorları, taburcu olanlardan istatistiksel olarak anlamlı şekilde yüksek saptanmıştır $(p<0,01)$. Aynı durum GKS skorları için de geçerlidir $(p<0,01)$ (Tablo 1).

YYBÜ'de hastaların \%62,3'ünde mekanik ventilatör desteği gerekti. En az 1, en fazla 35 gün mekanik ventilasyon uygulanmıştır. Ortalama mekanik ventilasyon süresi 6,94 $\pm 7,44$ gündür. Yoğun bakımda ölen hastalar mekanik ventilasyon intiyacı olup olmadığına göre ayrıldı. Ölen hastaların mekanik ventilasyon intiyacl, taburcu olan hastalardan istatistiksel olarak anlamlı şekilde yüksek saptanmıştır $(p<0,01)$. Ayrıca yoğun bakımda ölen hastalarda mekanik ventilasyon süresi de taburcu olanlardan istatistiksel olarak anlamlı şekilde yüksek saptanmıştır $(p<0,05)$ (Tablo 3$)$.

Hastaların \%6,6'sına hastanemiz Kulak Burun Boğaz Kliniği tarafından uzamış entübasyon ya da ödeme bağlı havayolu obstrüksiyonu endikasyonları ile trakeotomi açıldı. Trakeotomi açılan hastalarda mortalite oranı \% 71,4 olarak bulundu. Yoğun bakımda ölen hastalar incelendiğinde, trakeotomili hasta oranı, trakeotomili olmayanlardan istatistiksel olarak anlamlı şekilde yüksek saptanmıştır $(p<0,05)$ (Tablo 3).

Hemodinamisi stabil olmayan hastalara SIVI tedavisine ek olarak önce tekli, daha sonra ikili ve üçlü inotrop tedavileri eklendi. Hastaların \%58'ine (70 hasta) inotrop desteği başlandı. En sık tekli inotrop destek tedavisi uygulandı. Inotrop kullanım süreleri $1-3,4-5,6-10$ ve 10 gün ve üzeri olarak ayrlarak incelendi. Hastaların \%83'üne 1-3 gün süreyle inotrop tedavisi uygulandığı görüldü. Yoğun bakımda ölen hastalarda inotrop tedavi, taburcu

Tablo 3. Mekanik ventilasyon intiyacı, trakeotomi uygulaması, inotrop desteği-mortalite ilişkisi

\begin{tabular}{|c|c|c|c|c|}
\hline & & \multicolumn{2}{|c|}{ YYBÜ } & \multirow[t]{2}{*}{$\mathbf{P}$} \\
\hline & & Taburcu & Ölen & \\
\hline \multicolumn{2}{|c|}{ \#Mekanik Ventilasyon Süresi (gün) } & $5,24 \pm 5,93(3)$ & $7,63 \pm 7,90(5)$ & $0,048^{*}$ \\
\hline \multirow[t]{2}{*}{ Mekanik ventilasyon ihtiyacı } & Yok & $79(\% 67,5)$ & $1(\% 1,1)$ & \multirow{2}{*}{$0,001^{* *}$} \\
\hline & Var & $38(\% 32,5)$ & $94(\% 98,9)$ & \\
\hline \multirow[t]{2}{*}{ İnotrop desteği } & Yok & $114(\% 97,4)$ & $28(\% 29,5)$ & \multirow{2}{*}{$0,001^{* *}$} \\
\hline & Var & $3(\% 2,6)$ & $67(\% 70,5)$ & \\
\hline
\end{tabular}

Ki-kare testi kullanild, ${ }^{\#}$ Mann-Whitney U test, ${ }^{*} p<0,05,{ }^{* *} p<0,01$

Tablo 4. Mortaliteye göre üremelerin değerlendirmesi

\begin{tabular}{|c|c|c|c|c|}
\hline & & $\begin{array}{c}\text { Taburcu olan hasta sayısı } \\
\text { n (\%) }\end{array}$ & $\begin{array}{c}\text { Ölen hasta sayısı } \\
\mathbf{n}(\%)\end{array}$ & $\mathbf{P}$ \\
\hline $\begin{array}{l}\text { Kanda } \\
\text { Üreme }\end{array}$ & $\begin{array}{l}\text { Yok } \\
\text { Var }\end{array}$ & $\begin{array}{l}10(\% 28,6) \\
25(\% 71,4)\end{array}$ & $\begin{array}{l}19(\% 36,5) \\
33(\% 63,5)\end{array}$ & 0,440 \\
\hline $\begin{array}{l}\text { Kateterde } \\
\text { Üreme }\end{array}$ & $\begin{array}{l}\text { Yok } \\
\text { Var }\end{array}$ & $\begin{array}{l}25(\% 71,4) \\
10(\% 28,6)\end{array}$ & $\begin{array}{l}50(\% 96,2) \\
2(\% 3,8)\end{array}$ & 0,001 \\
\hline $\begin{array}{l}\text { Yara/dokuda } \\
\text { Üreme }\end{array}$ & $\begin{array}{l}\text { Yok } \\
\text { Var }\end{array}$ & $\begin{array}{l}13(\% 37,1) \\
22(\% 62,9)\end{array}$ & $\begin{array}{l}18(\% 34,6) \\
34(\% 65,4)\end{array}$ & 0,809 \\
\hline $\begin{array}{l}\text { İdrarda } \\
\text { Üreme }\end{array}$ & $\begin{array}{l}\text { Yok } \\
\text { Var }\end{array}$ & $\begin{array}{c}30(\% 85,7) \\
5(14,3)\end{array}$ & $\begin{array}{l}44(\% 84,6) \\
8(\% 15,4)\end{array}$ & 0,888 \\
\hline $\begin{array}{l}\text { Trakeada } \\
\text { Üreme }\end{array}$ & $\begin{array}{l}\text { Yok } \\
\text { Var }\end{array}$ & $\begin{array}{c}30(\% 85,7) \\
5(\% 14,3)\end{array}$ & $\begin{array}{l}32(\% 61,5) \\
20(\% 38,5)\end{array}$ & $0,0015^{*}$ \\
\hline
\end{tabular}

Ki-kare testi, ${ }^{*} p<0,05$ 
olanlardan istatistiksel olarak anlamlı şekilde yüksek saptanmıştır $(p<0,01)$ (Tablo 3).

Hastaların ölüm nedenleri sepsis, ARDS ve çoklu organ yetmezliği olarak sınıflandırılı. Kaybedilen hastaların \%37'sinde mortalite nedeni çoklu organ yetmezliği, \%32'sinde sepsisti.

Hastaların kan, doku/yara, trakea ve idrar kültürleri incelendi. Elli altı hastada doku ve yara, 58 hastada ise kanda üreme saptandı. Doku ve yarada en fazla üreyen mikroorganizma nonfermantatif gram negatif basil iken, kanda en fazla üreyenler Pseudomonas ve A. baumannii idi. Mortaliteye göre kanda üreme görülme durumları arasında istatistiksel olarak anlamlı farklılık bulunmamaktadır ( $p>0,05$ ) (Tablo 4).

Yoğun bakımda kaybedilen olgularda kateterde üreme oranı taburcu olan olgulardan istatistiksel olarak anlamlı şekilde düşük saptanmıştır $(p<0,01)$. Yara/dokuda üreme görülme ile mortalite arasında istatistiksel olarak anlamlı farklııı bulunmamaktadır ( $p>0,05)$ (Tablo 4).

Mortaliteye göre idrarda üreme görülme durumları arasında istatistiksel olarak anlamlı farklılık bulunmamaktadır ( $p>0.05$ ). Yoğun bakımda ölen hastalarda trakeada üreme oranı taburcu olanlardan istatistiksel olarak anlamlı şekilde yüksek saptanmıştır $(p<0,05)$ (Tablo 4).

Tek değişkenli ölçümlerde anlamlı bulunan; yanık düzeyi, yaş, mekanik ventilasyon, trakeotomi varlığı, inotrop varlığı, gelişte ve 24 saattlik APACHE II skorları ve GKS skoru parametrelerinin etkilerini regresyon analizi ile değerlendirdiğimizde; modelin ileri düzeyde anlamlı $(p<0,001)$ bulunduğu ve Negelkerke $R$ square değerinin 0,792 olarak saptandığı, modelin açıklayıcılık katsayısının $(\% 81,3)$ çok iyi düzeyde olduğu görüldü. Modele yanık düzeyinin, mekanik ventilasyon varlığının, inotrop varlığının ve 24 saatlik APACHE II skorlarının etkileri istatistiksel olarak anlamlı bulunmuştur ( $p<0,05)$. Yanık düzeyi artışının 1,039 kat, mekanik ventilasyon varlığının 21.547 kat, inotrop gereksiniminin 19,027 kat ve 24 saatlik APACHE II skoru artışının 1,195 kat mortalite riskini arttırıcı etkisi olduğu görülmüştür.

\section{Tartışma}

Yanık bakımı ve tedavisi hem hasta hem de klinisyenler açısından karmaşık ve uzun bir süreçtir. Çünkü bu süreci etkileyen birçok neden vardır. Bu çalışmada da bu nedenlerin bazıları incelenmiştir.

Çalışmada, yanık yoğun bakım ünitesinde takip edilen 212 hastanın 48'i $(\% 22,6)$ kadın, 164'ü $(\% 77,4)$ erkek olduğunu

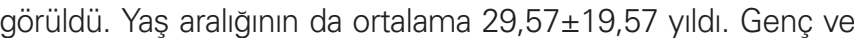
erkek hastaların daha fazla olması, genç erkeklerin sosyal hayatta daha aktif olmasından kaynaklanmaktadır.

Vücut yüzey alanının \%90-95'i yanık olan çocukların \%50 sağkalım şansı vardır. Tüm vücudu ciddi şekilde yanmış, tedavinin endike olmadığı düşünülen çocuk hastalarda belli bir süre yine de tedavi verilmelidir. Erişkin yanık hastalarında ise üç risk faktörü artmış ölüm riski açısından önemlidir: yaşın 60 üstü olması, inhalasyon hasarı, vücut yüzey alanının \%40'ın üzerinde yanık olması. Mortalite risk faktörleriyle paralel olarak bir risk faktöründe $\% 0,7$, iki risk faktöründe \%14, üç risk faktöründe \%39 olarak belirlenmiştir (4). Bu çalışmada da yanık yüzey alanı \% 70 ve üzeri olan hastalarda mortalitenin \%100 olduğu görüldü. Ayrıca ölen hastaların yaş ortalamasının tabucu olanlardan istatistiksel olarak anlamlı derecede yüksek bulundu.

Alev yanığına bağlı ölümlerin \%50'den fazlasında hastada asıl neden ISI ve duman inhalasyonu sonucu meydana gelen pulmoner yetersizliktir (5). Bu çalışmada da YYBÜ'e en sık yatış endikasyonu alev yanığı olarak bulundu. Alev yanığı olan 101 hastanın \%22'si yoğun bakımdan taburcu oldu.

Çalışmada alev yanığından sonra en sık yatış nedeni elektrik yanıklarıydı (\%23).

Maghsoudi ve arkadaşlarının yaptığı çalışmada elektrik yanığına maruz kalan hastaların mortalitesi \%2 olarak bulunmuştur (6). Hastalarının \% 7,4'üne amputasyon gerekli olmuştur. Anormal EKG'si olan hastalar monitörize edilmiş ve 4 hastada kardiyak komplikasyon ortaya çıkmıştır (6). Olgularımızda; elektrik yanığı olan her hasta aritmi açısından yoğun bakım ünitesinde 24 saat takip edildi. Kırk dokuz elektrik yanığı olan hastadan sadece 1 hastaya amputasyon uygulandı, 1 hasta kardiyak arrest nedeniyle kaybedildi. Mortalite \%31 olarak hesaplandı.

Yoğun bakım ünitesinde TEN tanılı hastalar da takip edildi. Steroidler, karbamazepin, nonsteroid antiinflamatuar ilaçlar, antiepileptikler gibi ilaçların kullanımına bağlı ortaya çıkan TEN'de mortalite \%30 civarındadır (7). Çalışmada yanık dışında TEN tanıı 7 hasta YYBÜ'de takip edildi. Mortalite \%29 olarak hesaplandı.

Yanık hastalarında yoğun sıvı tedavisine başlamadan önce sıvı tedavisine ek olarak inotrop destek tedavisi kullanmak yetersiz perfüzyona neden olur. Yanığı olmayan hastaların tersine yanık hastalarında kalp debisini yükseltmek için kalbin ön yükünü normale getirmeye çalışmak zordur (8). Çalışmada ortalama arter basıncı 60 mmHg'nın ve idrar çıkışı 0,5 ml/kg/saat altında olan hastalara sıvı tedavisine ek olarak inotrop tedavi başlandı. Önce tekli (dopamin infüzyonu), daha sonra ikili (dopamin ve dobutamin infüzyonu) ve en son üçlü (dopamin, dobutamin ve adrenalin infüzyonu) inotrop tedavileri eklendi. Ölen hastalarda inotrop tedavisi, taburcu olanlardan daha yüksekti. Bu istatistiksel olarak da anlamlıydı. Hastaların bu kadar yoğun inotrop tedavisine rağmen mortalitelerinin yüksek olması hastaların yanık şoku olarak tanımlanan tabloda olduğunu göstermektedir. Yanık yüzeyinin fazla olması nedeniyle artmış mikrovasküler geçirgenlik ve miyokardiyal yetersizlik inotrop tedaviye yanıtı azaltmıştır, tedavi kaybı karşılayamamaktadır.

Baş-boyun yanıkları ve inhalasyon yanıklarında uzamış entübasyon ya da ödeme bağlı havayolu obstrüksiyonu endikasyonları ile Kulak Burun Boğaz Kliniği tarafından trakeotomi açıldı. YYBÜ'de ölen hastalar incelendiğinde, taburcu olan hastalarda daha fazla trakeotomi açılmış olduğu görüldü. Bu yanığı olmayan hastalarda beklenen bir sonuç değildi. Geniş çaplı 
randomize çalışmalarla ispatlanmış olmasa da trakeostominin, mekanik ventilasyon süresini kısalttığına, ventilatöre bağlı pnömoni insidansını azalttığına, hastanın yoğun bakımdan taburculuğunu sağladığına inanılmaktadır (9). Ancak yanık hastalarında akciğer hasarı, diğer hastalardan daha fazladır. Bu da tedavinin daha da zorlaşmasına neden olur. Saffle ve ark. (10) erken trakeostominin yanık hastalarındaki potansiyel yararını değerlendirmek amacıyla çalışma yapmışlardır. Çalışma sonucunda entübe hastalarla erken trakeostomi açılan hastalarda ventilatör desteği, yatış süreleri, pnömoni insidansı ya da sağkalım açısından fark bulamamışlardır. Bunu da trakeostominin kısmen daha rahat ve elverişli olmasına bağlamışlardır. Aggarwal ve ark.(11) yanık hastalarını geriye yönelik olarak hasarın büyüklüğü, trakeostomi endikasyonu, yatış süresi sonuçları, mekanik ventilasyon süresi, havayolu ve pulmoner komplikasyonlar ve sağkalım açısından değerlendirmişlerdir. Çalışmalarının sonucunda mekanik ventilasyon süresi, hastane yatış süresi ve pulmoner sepsis insidansını trakeostomili hastalarda belirgin olarak yüksek bulmuşlardır (11).

Hastaların YYBÜ ve hastane yatış süreleri incelendiğinde YYBÜ'de ölen hastalarda yatış süresi anlamlı derecede yüksek bulunmuştur ( $p<0,01)$. YYBÜ'de 13-35 gün (ortalama 7,66 $\pm 7,84$

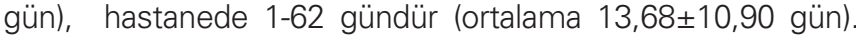
Demirel ve ark. (12) yanık ünitesinde yaptıkları çalışmada yatış

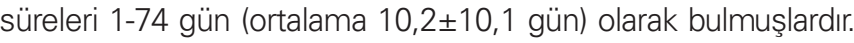
Bu sonuç da çalışmadaki hastane ortalamasına yakındır.

Gomez ve ark. (13), 12 yıllık periyotta geriye yönelik olarak akut termal yanıklı hastaları incelemişler. Artan yaş, 1. gün APACHE II skoru, yanık yüzdeleri ve cinsiyetin mortalitenin güçlü belirteçleri olduğunu söylemişlerdir. Bu çalışmada da yatıştaki ve yatıştan 24 saat sonraki APACHE II skorlarına bakıldı. Yoğun bakımda ölen hastalarda, taburcu olanlara göre iki skor da anlamlı derecede yüksek bulundu. Iki skor kendi arasında değerlendirildiğinde ise 24 saat sonraki skorlar, yatıştakinden daha düşüktü. Yirmi dört saat sonraki skorun düşük olmasının nedeni tedavinin başlanması, hemodinaminin daha istikrarlı hale getirilmesidir.

Yorgancı ve ark.'nın (14) yanık ünitesinde yaptıkları çalışmada en sık mortalite nedenini tüm gruplarda sepsis (\%62,2), akut dönem sıvı resüsitasyonu başarısızlığı $(\% 18,9)$ ve çoklu organ yetmezliği $(\% 10,9)$ olarak bulmuşlardır (14). Bu çalışmada da hastaların yaş aralıkları daha geniş olsa da mortalite nedenleri sepsis ve çoklu organ yetmezliği olarak bulunmuştur.

YYBÜ mortalitesi \%44,8 olarak hesaplandı. Taburcu olan hastaların \%2,8'nin tekrar yoğun bakıma alındığı görüldü. Bu hastaların da mortalitesi \%83'tü. Tekrar yoğun bakıma alınma nedeninin hastaların geçirdiği mükerrer yıkama işlemi ve operasyonlar sonucu enfeksiyonun yinelemesi olduğu düşünüldü.

Günümüzde yanık hastalarında ölümlerin \%75'ine hipovolemik şok ya da osmotik şok yerine enfeksiyonlar neden olmaktadır. Yanık yüzeyi travma sonrası çoğunlukla steril iken, kısa süre içinde mikroorganizmalarla kontamine hale gelir. Yanık travmasının türü ve büyüklüğüne bağlı olarak kolonize olan mikroorganizma sayısı ve derinliği değişir (15). Çalışmada hastalardan alınan kan, doku/yara, trakea, santral kateter ucu ve idrar kültürleri incelendi. Kanda en fazla Pseudomonas aeruginosa ve Acinetobacter baumanii, doku/yarada non-fermantatif gram negatif basil, kateter ucunda non-fermantatif gram negatif basil, A. baumanii ve Candida, trakeada non-fermantatif gram negatif basil ve P. aeruginosa, idrarda ise kandida ve P. aeruginosa üremesinin fazla olduğu görüldü. Istatistiksel olarak üremeler ayrı ayrı incelendiğinde mortalite açısından yoğun bakımda ölen hastalarla taburcu olan hastalar arasında anlamlı fark trakeada üreme haricinde saptanmadı. Yoğun bakımda artmış invazif girişim nedeniyle enfeksiyon gelişimi kolaylaşır. Trakeadaki üreme de entübasyon tüpü boyunca ilerleyerek akciğerlere ulaşır ve zaten hasarlı olan dokunun enfeksiyon riskini arttırabilir. Trottier ve ark. (16) yaptıkları çalışmada A. baumanii enfeksiyonunu yanık yoğun bakım hastalarında önemli derecede fazla bulmuşlardır. Polat ve ark. (17) yara yeri sürüntülerini incelemişlerdir. En sık P. aeruginosa $(\% 21,2)$ ve metisiline dirençli Staphylococcus aureus $(\% 19,7)$ ile karşılaşılmış. Gram negatif mikroorganizmalarla kolonize olan olgularda ortalama hastane kalış süresi anlamlı olarak daha uzun bulunmuş. Yanıklı hastalarda yanık enfeksiyonlarının kontrolü için öncelikle yanık alanının kontaminasyonunun engellenmesini ve tam izolasyon sağlanmasını önermişlerdir. Öncül ve ark. (18) ise yanık bakım ünitesinde nazokomiyal enfeksiyonların ileri dönük analizini gösteren bir çalışma yapmışlardır. Hastaların yara yerinde en sık P.aeroginosa (\%57), A. baumanni (\%21) ve S. aureus (\%14) tespit etmişlerdir.

\section{Sonuç}

Ülkemizde yanık yoğun bakım ünitesinde yapılmış kapsamlı bir çalışma bulunmamaktadır. Bu çalışmada yanık yoğun bakımda takip edilen hastaların prognozunu etkileyen faktörleri tespit etmeyi amaçladık. Beklenildiği gibi yanık düzeyinin fazla olması ve APACHE II skorunun yüksek olması mortaliteyi olumsuz etkilemektedir. Mekanik ventilasyon uygulamasının ve inotropik destek tedavisinin ise beklenilenin tersine mortalite riskini arttırıcı etkisi olduğu görüldü. Mekanik ventilasyonun etkilemesinin nedenini hastaların akciğerlerinin, inhalasyon hasarına bağlı olarak diğer yoğun bakımda yatan hastalardan daha fazla hasarlı olmasına bağladık. Çalışmamızda mekanik ventilasyon ihtiyacını yanık nedenlerine göre ayırmadık, çünkü hastalarımız patlama, yangın gibi nedenlerle yanığa maruz kalmışlardı. Bundan sonraki çalışmalarda mekanik ventilasyon ihtiyacının yanık nedenlerine göre tanımlanmasının tedaviyi yönlendirebileceği düşüncesindeyiz. Inotrop tedavisine yanıtın azalmasının, yanık yüzeyinin fazla olması nedeniyle mikrosirkülasyonun bozulması ile ilişkili olabileceği kanaatindeyiz. 
Hastaların kan, doku/yara, trakea ve idrar kültürleri ile mortalite arasında anlamlı bir fark bulunmamıştır. Yanık yoğun bakım ünitelerinde kontaminasyon kaynaklarının birden fazla olması ve yanığa bağlı olarak hastaların immün sistemindeki zayıflama nedeniyle enfeksiyon riski fazladır. Bu nedenle hastalarda daha üreme bașlamadan sterilizasyon kurallarına dikkat edilmelidir ve yanık tedavi merkezlerinin düzenlenmesi sterilizasyona uygun şekilde olmalıdır.

\section{Kaynaklar}

1. Sheridan R., Grecu L., Yanık hastası, Çeviri: Özen G., Iskit A., Critical Care Handbook of the Massachusetts General Hospital, 4.baskı, Ankara, Güneș kitapevleri, 2010, s 656-79.

2. Demling R., Desanti L., Burns: Resustation phase, In: Hall JB,Schmidt GA, Wood L., Principles of critical care, third edition, USA, McGraw-Hill, 2005, page 1457-65.

3. Wolf S.E, Pruitt B.A, Burn Managment, Intensive Care Medicine, sixth edition, USA, Lippincot Williams\&Wilkins, 2008, page 1930-1.

4. Parviainen I., Yanıklar, Inhalasyon ve Elektrik hasarları, Çeviri: Yıldırım A., Klinik Yoğun Bakım, 1.baskı, İstanbul tıp kitapevleri, Istanbul, 2009, s 618-9.

5. Demling R., Desanti L., Burns: Inflamationinfection phase, In: Hall JB,Schmidt GA, Wood L., Principles of critical care, third edition, USA, McGraw-Hill, 2005, page 1473-7.
6. Maghsoudi H., Adyani Y., Ahmadian N., Electrical and Lightning Injuries, Journal of Burn Care\&Reaserch, March/ April 2007;28:255-1.

7. Bastuji-Garin S, Fouchard N, Bertocchi M, Roujeau JC, Revuz J, Wolkenstein P. A SCORTEN: a severity-of-illness score for toxic epidermal necrolysis. J Invest Dermatol 2000;115:149-53.

8. Demling R., Desanti L., Burns: Resustation phase, In: Hall JB,Schmidt GA, Wood L., Principles of critical care, third edition, USA, McGraw-Hill, 2005, page 1457-65.

9. Heffner JE. The Role of Tracheostomy in Weaning. Chest 2001;120:477-81.

10. Saffle JR, Morris SE, Edelman L. Early Tracheostomy Does not Improve Outcome in Burn Patients. J Burn Care Rehabil 2002;23:431-8.

11. Aggarwal S, Smailes $S$, Dziewulski P. Tracheostomy in Burns Patients Revisited. Burns 2009;35:962-6.

12. Demirel Y,Çöl C, Özen M. Ankara Numune Eğitim ve Araştırma Hastanesi Yanık Servisinde Bir Yılda Izlenen Hastaların Değerlendirilmesi, C. Ü. Tıp Fakültesi Dergisi 2001;23:15-20.
13. Gomez M, Wong DT. The FLAMES Score Accurately Predicts Mortality Risk in Burn Patients. J Trauma 2008;65:636-45.

14. Yorgancı K, Elker D, Kabay B, Kaynarğlu V, Öner Z, Sayek I. Kırkbeş Yaş Üstü Yanık Hastalarında Tedavi Sonuçları. Turkısh Journal of Geriatrics 2001;4:116-9.

15. Öncül O. Yanık Enfeksiyonları, Hastane enfeksiyonları korunma ve kontrol sempozyum dizisi 2008;60:105-19.

16. Trottier V, Segura PG, Namias N, King D, Pizano LR, Schulman $\mathrm{Cl}$. Outcomes of Acinetobacter baumannii Infection in Critically III Burned Patients. J Burn Care Res 2007;28:248-54.

17. Polat $Y$, Karabulut $A, B a l c ı$, , Cilengir $M$, Övet G, Cebelli S. Yanık olgularında kültür ve antibiyogram sonuçlarının incelenmesi. Pam Med J 2010;3:131-5.

18. Oncul O, Ulkur E, Acar A, Turhan V, Yeniz E, Karacaer Z, et al. Prospective analysis of nosocomial infections in a Burn Care Unit, Turkey. Indian J Med Res 2009;130:758-64. 